\title{
A Study of Investors Perception towards Mutual Funds in the City of Delhi and Meerut
}

\section{Khan $\mathrm{AH}^{*}$ and Agarwal SK}

Monad University, Uttar Pradesh, India

\begin{abstract}
Mutual fund is an investment vehicle that pools in the monies of many investors, and collectively invests this amount in either the equity market or the debt and money market, or both, depending upon the objective of the scheme. This means one can access either the equity or the debt market, or both, with investing directly now mutual do innovation into objective of fund by introducing liquid fund by putting some amount in this fund money slowly move to desired fund without losing any benefit.

My study is conducted in Delhi and Meerut areas in different public sector and private banks. By asking close ended and open-ended questioners. We observed that despite being a lot of bombarding of continuous advertising by Mutual fund houses still investors of tier two cities are not believing on private mutual fund but in case of metro like Delhi are more aware and eager to invest in private and PSU mutual funds. In our study we touch student's business man and working people of middle class. And found that people are hungry to invest in Good Avenue, but they are not getting proper counseling in their own language or in simple way. I meet during the data collecting process many ordinary and less educated person who knows a lot about mutual funds but at end of the day they are not ready to put their hard earn money in any private funds and private equity.
\end{abstract}

Keywords: Asset Management Company (AMC); Investment option; Investor; Liquidity; Mutual fund

\section{Introduction}

Mutual Fund investments are subject to market risks, read all scheme related documents carefully. Mutual funds are investment companies that collect funds from individual investors and invest those funds in a potentially wide range of securities or other assets. Pooling of assets is the key idea behind forming these investment companies. Each investor has a claim to the portfolio established by the investment company in proportion to the amount invested. These companies thus provide a mechanism for small investors to pool their funds to get benefits of large scale investing $[1,2]$.

\section{Rationale of the study}

My study based on the fact rather than pure assumptions about the mutual fund schemes cater for different category of people and give clear understanding about schemes and break the myth about the mutual that only few selected institutional investor and AMCs are benefited [3]. And rest is loser and expense ratio are hidden and entry load is low and exit load is very high. Every investor has equal awareness about mutual whether belong to tire two cities or metros. Picture is quite different all myth about the mutual are came out of rather serious research. So, my research tries to answer those entire questions arise in mind of common investor about the subject.

\section{Structure of mutual fund}

There are three parties in mutual fund

1. Sponsor

2. Trustee

3. AMC

4. First entity- sponsor, qualification of sponsor, good reputation, increasing order of profit for last 5 years

5. Custodian
6. Second- trustee, $2 / 3^{\text {rd }}$ member of should not from sponsors

7. Third-AMC.in case AMC 50\% members should be independent

8. In mutual fund

9. Our relation is trustee and Beneficiary

10. Sponsor will be any banks or financing company, after taking prior permission from SEBI. Sponsor develops a trust and according to trust deed AMC is formed. Start functioning of mutual fund activities. Schemes are design according to need of investors (Figure 1) [4].

\section{Types of mutual fund scheme}

Mutual Fund schemes can be classified into different categories depends on their investment goals or their maturity time. Mutual fund schemes can be classified into three categories based on their maturity periods.

Open-ended funds: An open-ended fund or scheme is one that is available for subscriptions and redemptions on a continuous basis. Investors can willingly sell and buy units at Net Asset Value (NAV) related prices which are declared on weekly bases [5].

Close-ended funds: A close-ended fund or scheme has a variable maturity period which can range from a few months to a few years, e.g., 6 months, 6 years or 10 years. i.e., fund is open for subscription only

*Corresponding author: Abbul Hasan Khan, Research Scholar, Monad University, Uttar Pradesh, India, Tel: 01222327000; E-mail: ah.khan079@gmail.com

Received November 20, 2017; Accepted November 27, 2017; Published December 072017

Citation: Khan AH, Agarwal SK (2017) A Study of Investors Perception towards Mutual Funds in the City of Delhi and Meerut. J Bus Fin Aff 6: 306. doi: 10.4172/2167-0234.1000306

Copyright: @ $2017 \mathrm{Khan} \mathrm{AH}$, et al. This is an open-access article distributed under the terms of the Creative Commons Attribution License, which permits unrestricted use, distribution, and reproduction in any medium, provided the original author and source are credited. 


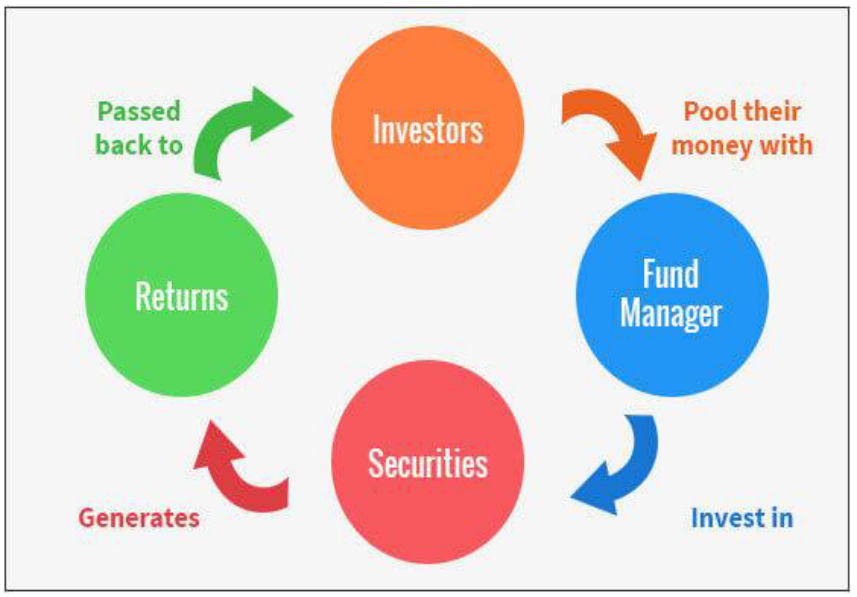

Figure 1: Structure of mutual fund.

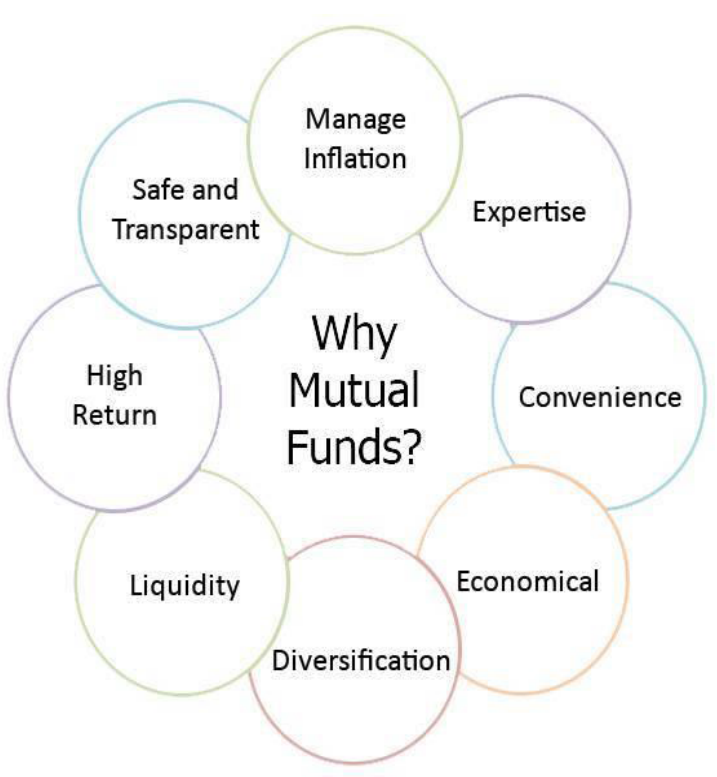

Figure 2: Advantages of mutual fund.

during a specified period at the time of launch of the scheme.

Interval funds: These schemes are a cross between an open-ended and a close-ended structure. These schemes are open for both purchase and redemption during pre-specified intervals (viz. monthly, quarterly, annually etc.) at the prevailing NAV based prices. Interval funds are very similar to close-ended funds, but differ on the following points:

(1) They are not required to be listed on the stock exchanges.

(2) They can make fresh issue of units during the specified interval period, at the prevailing NAV based prices.

(3) Maturity period is not defined.

\section{Advantages of mutual fund}

1. Manage inflation

2. Safe and transparent

3. High return
4. Diversification

5. Liquidity (Figure 2).

\section{Objectives of study}

1. To know investor view towards Mutual fund.

2. To know the preference of investor toward specific instrument.

3. To know the level of awareness of mutual funds in metro and other cities and study the investor behavior in mutual fund schemes.

\section{Research Methodology}

\section{Source of data}

The present study is based on primary data which was collected using questionnaire method. 
Citation: Khan AH, Agarwal SK (2017) A Study of Investors Perception towards Mutual Funds in the City of Delhi and Meerut. J Bus Fin Aff 6: 306. doi: $10.4172 / 2167-0234.1000306$

\section{Data collection}

The data was collected using questionnaire from professionals/ common man like those who wants invest in mutual funds and other investment option.

\section{Hypothesis}

1. Investors have mix opinion about mutual fund

2. Investors are more interested about known instruments

3. Investors of metros are more aware about mutual fund (Appendix 1).

\section{Data analysis and interpretation}

From Table 1,

Sigma $X=200,000+300,000+400,000+500,000+600,000+800,000+1$ $0,00,000$

\begin{tabular}{|c|c|c|}
\hline Age group & Profession/Number & Income \\
\hline $25-30$ & Student/20 & $100,000-200,000$ \\
\hline $35-40$ & Clerk/15 & $200,000-300,000$ \\
\hline $40-45$ & Bank employee/10 & $300,000-400,000$ \\
\hline $45-50$ & Teacher/20 & $400,000-500,000$ \\
\hline $55-60$ & Advocate/15 & $500.000-600,000$ \\
\hline $60-65$ & Business man/10 & $600,000-800.000$ \\
\hline Above & Retired person/10 & Tax $/ 0,00000$ \\
\hline
\end{tabular}

Table 1: (Meerut) Give preferences of investor to different instruments.

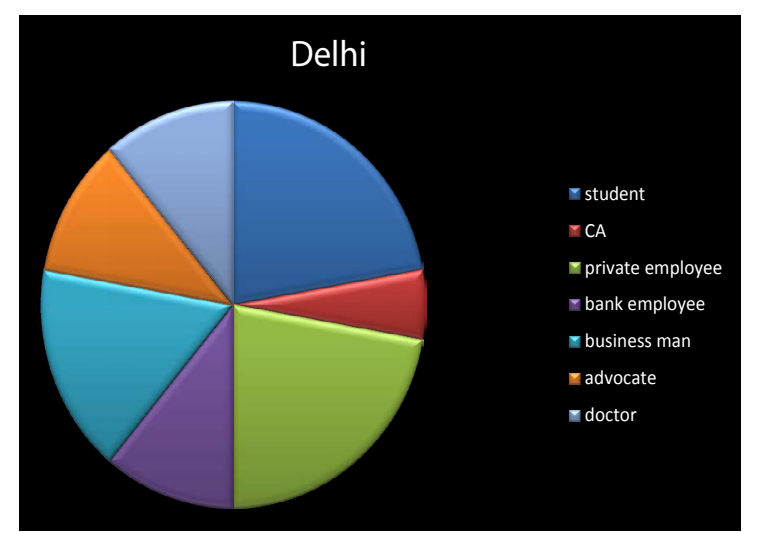

Figure 3: Pie chart shows different perception of different people of Delhi.

\section{Meerut}

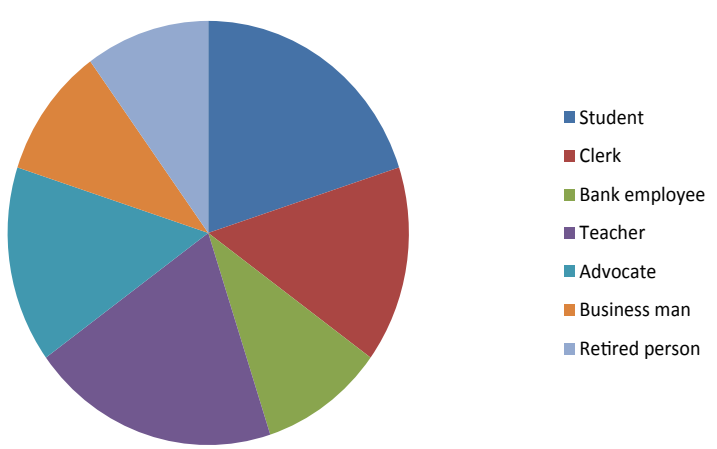

Figure 4: Pie chart shows different perception of different people of Meerut.
$=38,00,000$

$\mathrm{N}=100$

Mean of income $=38.000$

Sigma of $X=30+40+45+50+60+65+70$

$=360$

$\mathrm{N}=100$

Mean of age $=3.6$ year insignificant .

After computing these mean we conclude about the perceptions (Figures 3 and 4) [6].

\section{Results and Analysis}

Graphical presentation age and income (Figure 5).

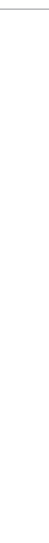


Citation: Khan AH, Agarwal SK (2017) A Study of Investors Perception towards Mutual Funds in the City of Delhi and Meerut. J Bus Fin Aff 6: 306. doi: $10.4172 / 2167-0234.1000306$

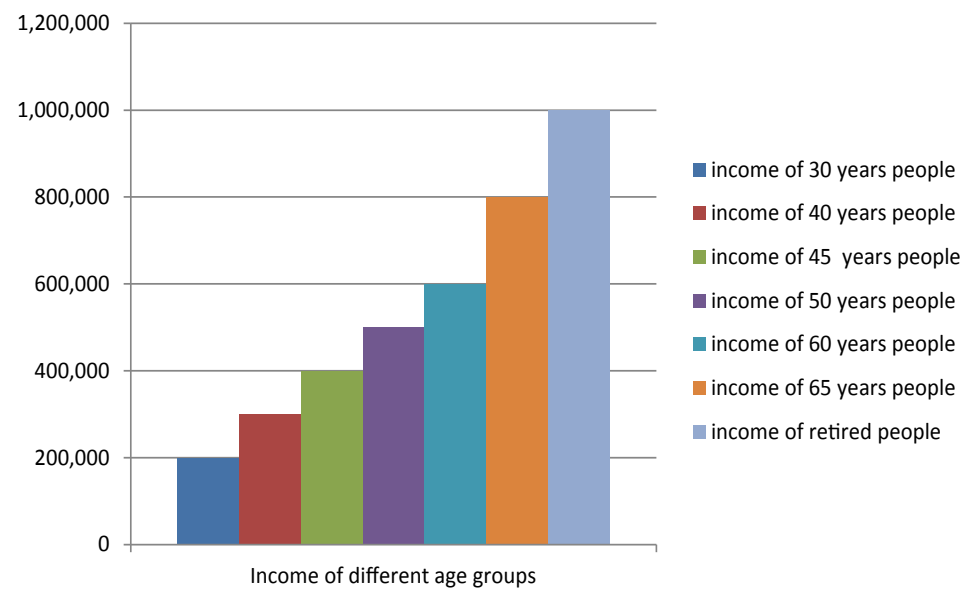

Figure 5: Graphical presentation age and income.

\section{Suggestions and finding of the study}

There are some suggestions based on our study for batter investing for investors that they should keep their investment for long time keeping in mind the level of risk involves and saving pattern investors first look over the risk factor because they are investing for the maximum returns [7]. Once they invested in mutual fund they need returns and if it is not giving proper returns to them again it is affecting the interest of the investors to invest in MF. There is need to work on ground level in tier two cities because there is huge potential but is still untapped. Expert people go for make people aware about financial product hold small gathering and show the documentary and return back to their home this is merely not possible. We should go and talk to them after knowing their future financial need things will surely improve like metro $[8,9]$. In my study I have taken three hypothesis and fund that on the bases of empirical studies found true. The findings show that mutual funds as an investment option have displayed tremendous growth potential when the markets are optimistic and when wise choices are made. They have performed much better than traditional investment options in the long term and thus help investor beat inflation to some extent. It is of paramount importance that investors do not make a rash decision simply by looking at the return figures generated by an individual fund, but investor belong to tire two cities are not aware about good news about mutual fund and stock market but news of scandal and miss happening reach very fast to them, so they scared.

\section{Conclusion}

The objectives of study towards mutual fund as per the sample size and method which is applied to the study and found that the investors are not choosing or feeling confident in investing in mutual fund because they think that mutual fund is risky than other investment options. The awareness level of mutual fund among the investors are very low because of only having the partial knowledge about the mutual fund which prevent them to Invest in mutual fund to avoid risk bearing factor and fear of losing money.

The objective of study to know about the perception of common investor about mutual funds of PSU and private entities in different cities. The awareness level of mutual fund among the investors are very low because of only having the little knowledge about the mutual fund which prevent them to invest in mutual funds. To avoid risk bearing factors and danger of great loss. What we observed there is enough money with them in tire two cities of people but they are in confusion in absence of awareness.

\section{References}

1. Dimple (2013) Comparative Study of Performance of SBI Mutual Fund, HDFC Mutual Fund and Birla Sun Life Fund-Growth Schemes. Journal of Advances and Scholarly Researches in Allied Education 12: 143-148.

2. Fischer DE, Jordan RJ (1995) Security Analysis and Portfolio Management. (6th edn.), Prentice Hall of India Pvt. Ltd, p: 598.

3. Pandian P (2016) Security analysis and Portfolio Management. (2nd edn.), p: 35.

4. Chandra $P$ (2009) Investment Analysis and Portfolio Management. (2nd edn.), Tata Mc Graw Hill Publishing Company Limited, New Delhi.

5. http://www.amfiindia.com/showhtml.aspx?page=mfindustry

6. http://www.sbimf.com/Index.aspx

7. Mane P (2016) A Study of Investors Perception towards Mutual Funds in the City of Aurangabad. The SIJ Transactions on Industrial, Financial and Business Management 4: 30-38.

8. Kothari PP, Mindargi SC (2013) A Study of Investors Attitude Towards Mutual Fund with Special Reference to Inversotrs in Solapur City. International Journal of Accounting and Financial Management Research 3: 1-12.

9. Radhika M (2017) A comparative study on investors' perception towards mutual fund and equity. International Journal of Research in Management, Science and Technology 5: 63-68. 